\title{
Pemberdayaan UMKM Kuliner dalam Manajemen dan Pemasaran Produk Secara Online pada UMKM di Kecamatan Jebres Surakarta
}

\author{
Bambang Hadinugroho ${ }^{1}$, Endang Suhari ${ }^{2}$, Harmadi $^{3}$, Heru Agustanto $^{4}$, Sri Hartoko ${ }^{5}$, Yohana Tamara ${ }^{6}$, \\ Sunarjanto $^{7}$, Sri Seventi Pujiastuti ${ }^{8}$ \\ 1), 2), 3), 4), 5), 6), 7)Fakultas Ekonomi dan Bisnis Universitas Sebelas Maret \\ Email: bambanghadinugroho@yahoo.co.id, endangsuhari61@gmail.com, \\ harmadiharsowardoyo@yahoo.co.id, Heru.agustanto@gmail.com, Sri.hartoko@yahoo.com, \\ tamarayohana@staff.uns.ac.id, Sunarjanto_fe@staff.uns.ac.id, seventipudjiastuti55@yahoo.com
}

\begin{abstract}
Abstrak
Jumlah Usaha Mikro Kecil dan Menengah (UMKM) merupakan bagian yang besar dari pelaku ekonomi secara keseluruhan. Namun perkembangan UMKM yang berkaitan dengan kemajuan teknologi informasi (IT) masih belum sesuai harapan. Proporsi UMKM yang menggunakan penjualan online masih rendah. Hal itu disebabkan oleh masih banyak UMKM yang belum mengenal secara teknis tatacara penjualan online, untung rugi, dan prosedur aplikasinya.Tujuan pengabdian masyarakat ini adalah peningkatan kemampuan UMKM dalam manajemen secara umum, keuangan, pemasaran secara online, serta dapat mempromosikan produknya melalui penjualan online dengan bermitra dengan Go-Jek. Metode yang digunakan dalam pengabdian ini adalah pelatihan, pendampingan, dan memberikan petunjuk aplikasi dalam penjualan online melalui Go-Food. Peserta pelatihan sebanyak 15 usaha kuliner yang diberi pelatihan manajemen yang mereka butuhkan. Pelatihan ini disertai dengan pendampingan terhadap mitra binaan tersebut hingga mereka dapat melakukan penjualan secara online dan dapat mengelola usaha dengan baik. Hasil yang diperoleh dari kegiatan ini adalah terbentuknya mitra binaan kuliner yang lebih maju dalam pengelolaan dan penjualan produk secara online, dan mereka sudah bergabung dengan GoJek untuk menjual produk melalui Go-Food.
\end{abstract}

Kata kunci: pelatihan manajemen, penjualan online, Go-Food

\section{PENDAHULUAN}

Informasi dari Kementerian Koperasi dan Usaha Kecil Menengah (Kemenkop UKM) menyebutkan bahwa sejumlah 3,79 juta usaha mikro, kecil, dan menengah (UMKM) sudah memanfaatkan teknologi digital online dalam memasarkan produknya. Jumlah tersebut setara dengan 8 persen dari total UMKM yang ada di Indonesia, yaitu sebanyak 59,2 juta. Namun jumlah tersebut belum memadai, jika memperhatikan pertumbuhan teknologi informasi seperti yang terjadi pada saat ini. Untuk menumbuhkan jumlah pelaku UMKM yang memasuki di dunia maya, Kementrian Koperasi dan UKM, beserta Kementerian Komunikasi dan Informatika (Kemkominfo), mempunyai gagasan berupa program bertajuk 8 Juta UMKM Go Online. Program ini mengharapkan agar 8 juta UMKM tersebut dapat menjadi pelaku utama pada UMKM yang menggunakan go online. Kementerian Komunikasi dan Informatika (Kominfo) RI mendorong pelaku usaha kecil dan menengah (UMKM) untuk mulai beralih ke pasar online.

Ekonomi, Sosial dan Budaya 1015 
Dalam kehidupan sehari-hari selalu terlihat pemandangan sehari-hari yang tak lepas dari layanan pelaku UMKM. Sejak pagi hari dijajakan sarapan pagi yang dijual oleh pelaku UMKM, belanja kebutuhan pokok, dan sampai jasa-jasa layanan lainnya dari UMKM tersebut. Pada era perkembangan digital, layanan-layanan tersebut bisa lebih dipermudah dengan hadirnya layanan yang didukung oleh teknologi digital. Bahkan, para pelaku UMKM tersebut tidak harus memiliki toko, tetapi bisa dikerjakan di rumah sendiri dengan penjualan melalui bantuan teknologi digital tersebut.

UMKM mempunyai peranan penting atau kontribusi yang sangat besar pada perekonomian. Kementerian Koperasi dan UKM RI menginformasikan bahwa dilihat dari jumlah unit, UMKM memiliki pangsa sekitar 99,99\% (62.9 juta unit) dari total keseluruhan pelaku usaha di Indonesia (2017). Sedangkan usaha besar hanya sebanyak $0,01 \%$ atau sekitar 5400 unit. Usaha Mikro menyerap sekitar 107,2 juta tenaga kerja $(89,2 \%)$, Usaha Kecil 5,7 juta (4,74\%), dan Usaha Menengah 3,73 juta $(3,11 \%)$; sementara Usaha Besar menyerap sekitar 3,58 juta jiwa. Artinya secara gabungan UMKM menyerap sekitar $97 \%$ tenaga kerja nasional, sementara Usaha Besar hanya menyerap sekitar 3\% dari total tenaga kerja nasional.

Hal itu menunjukkan bahwa betapa besar peranan UMKM di dalam pembangunan perekonomian Indonesia. Berikut ini disajikan jumlah UMKM dan usaha besar yang ada di Indonesia pada tahun 2017. Pada tabel di bawah menunjukkan betapa penting peran UMKM pada perekonomian Indonesia. Memang kalau dibandingkan per unit perusahaan, misal satu perusahaan kecil dibandingkan dengan perusahaan besar, kemampuan perusahaan kecil akan jauh dibawah perusahaan besar. Tetapi bila dilihat kemampuan secara total, maka perusahaan besar akan kalah kontribusinya dibanding dengan perusahaan kecil.
Tabel 1

Kontribusi Kategori Skala Usaha Pada PDB Indonesia

\begin{tabular}{|l|r|r|r|r|r|}
\hline $\begin{array}{c}\text { Kategori } \begin{array}{c}\text { Skala } \\
\text { Usahla }\end{array} \\
\text { Mikro }\end{array}$ & $\begin{array}{c}\text { Jumlah } \\
\text { (unit) }\end{array}$ & $\begin{array}{c}\text { Persentasi } \\
\text { Unit } \\
\text { Usaha }\end{array}$ & $\begin{array}{c}\text { Total } \\
\text { Pendapatan } \\
\text { Usaha-harga } \\
\text { berlaku }\end{array}$ & $\begin{array}{c}\text { Persentasi } \\
\text { Kontribusi } \\
\text { terhadap } \\
\text { PDB }\end{array}$ & $\begin{array}{c}\text { Rata-rata } \\
\text { Pendapatan per unit } \\
\text { usaha (rupiah per } \\
\text { tahun) }\end{array}$ \\
\hline Kecil & 757.106 .900 & $98,70 \%$ & $4.727,99$ & $34,12 \%$ & $76.126 .646,15$ \\
\hline Mentengah & 58.627 & $0,11 \%$ & $1.742,44$ & $12,57 \%$ & $29.720 .777 .116,35$ \\
\hline Besar & 5.460 & $0,01 \%$ & $5.136,22$ & $37,07 \%$ & $940.699 .633 .699,63$ \\
\hline Total & 62.928 .007 & $100,00 \%$ & $12.841,00$ & $93,00 \%$ & \\
\hline
\end{tabular}

Jumlah UMKM yang dibina oleh Dinas Koperasi dan UMKM Kota Surakarta hingga akhir tahun 2018 sekitar 3.200 UMKM khusus di sektor produktif. Jumlah UMKM di Surakarta yang menjadi binaan Dinas Koperasi dan UKM mengalami peningkatan setiap tahunnya sekitar 10 persen. Peningkatan tersebut seiring dengan program penumbuhan wirausaha baru yang dilakukan setiap tahun, adapun potensi UMKM di Surakarta 43.700 buah termasuk pedagang pasar. Khusus untuk sektor produktif belum semua bisa dibina oleh Dinas Koperasi dan UKM Surakarta (Antaranews.com, 2019)

Surakarta merupakan kota industri kreatif yang berpotensi besar di pasar digital. Melalui program UMKM Go Online, pedagang di kota batik ini dapat memperluas area penjualan serta meningkatkan keuntungan para pelaku UMKM. Data dari Dinas Koperasi dan UKM menunjukkan bahwa jumlah UMKM Kuliner dan Makan Kemasan sebanyak 1786 unit. Persentase UMKM Kuliner pengguna aplikasi Go Food masih rendah, sehingga perlu sentuhan khusus untuk mendorong mereka agar segera melakukan penjualan online, dalam hal ini aplikasi Go Food dari Gojek.

Di atas telah diuraikan bahwa UMKM di Surakarta terus mengalami pertumbuhan seperti di daerah lainnya. Namun masih ketinggalan dalam hal manajemen, pemasaran produk dan penjualan secara online. Sehingga permasalahan UMKM Kuliner di Surakarta adalah: (1) pengetahuan manajemen usaha, yang meliputi manajemen umum sederhana, manajemen keuangan, dan manajemen pemasaran, pelaku UMKM kuliner masih rendah, (2) Pelaku UMKM Kuliner masih Ekonomi, Sosial dan Budaya 1016 
banyak yang mengandalkan penjualan secara konvensional, dan belum banyak yang mengenal dan menggunakan penjualan online melalui GoFood.

Dengan melihat permasalah tersebut, maka perlu dilakukan pengenalan dan pelatihan tentang manajemen bisnis, keuangan sederhana, dan pemasara produk melalui penjualan online. Para pelaku UMKM Kuliner saangat membutuhkan pengetahuan tersebut melalui pengenalan dan pelatihan sampai mereka mengaplikasikan dalam bisnisnya. Apabila hal itu dilakukan, maka kemampuan para UMKM Kuliner akan meningkat, sehingga akan mendorong kinerja mereka. Sehingga yang menjadi tujuan pengabdian masyarakat ini adalah peningkatan kemampuan UMKM dalam manajemen secara umum, keuangan, pemasaran secara online, serta dapat mempromosikan produknya melalui penjualan online dengan bermitra dengan Go-Jek.

\section{METODE}

Pencapaian tujuan peningkatan kemampuan UMKM dalam manajemen secara umum, keuangan, pemasaran secara online, serta dapat mempromosikan produknya melalui penjualan online dengan bermitra dengan GoJek, dilakukan pengenalan dan pelatihan tentang Manajemen, Keuangan, Pemasaran, dan Penjualan Online dengan Aplikasi Go-Food. Secara lebih terperinci metoda yang dilaksanakan bisa disajikan dalam tabel berikut.

Tabel 2

Metode Pengabdian kepada Mitra Binaan

\begin{tabular}{|l|l|l|l|}
\hline No & \multicolumn{1}{|c|}{ Jenis Permasalahan } & \multicolumn{1}{|c|}{ Metode yang digunakan } & \multicolumn{1}{c|}{ Sasaran } \\
\hline 1. & $\begin{array}{l}\text { Kurangnya Pengetahuan dan } \\
\text { Teknis Pengembangan } \\
\text { Manajemen Bisnis dari } \\
\text { Pelaku UMKM Kuliner }\end{array}$ & $\begin{array}{l}\text { Pengenalan Dan Pelatihan } \\
\text { Teknis Pengembangan } \\
\text { Mamajemen Bisnis }\end{array}$ & $\begin{array}{l}\text { Pelaku UMKM } \\
\text { Kuliner di } \\
\text { Kecamatan Jebres }\end{array}$ \\
\hline 2. & $\begin{array}{l}\text { Kurangnya Pengetahuan dan } \\
\text { Teknis Manajemen } \\
\text { Keuangan dari Pelaku } \\
\text { UMKM Kuliner }\end{array}$ & $\begin{array}{l}\text { Pengenalan dan Pelatihan } \\
\text { Analisis Manajemen } \\
\text { Keuangan Sederhana }\end{array}$ & $\begin{array}{l}\text { Pelaku UMKM } \\
\text { Kuliner di } \\
\text { Kecamatan Jebres }\end{array}$ \\
\hline 3. & $\begin{array}{l}\text { Kurangnya Pengetahuan dan } \\
\text { Teknis Manajemen } \\
\text { Pemasaran terutama } \\
\text { Penjualan Online dari Pelaku } \\
\text { UMKM Kuliner }\end{array}$ & $\begin{array}{l}\text { Pengenalan dan Pelatihan } \\
\text { Manajemen Pemasaran, } \\
\text { terutama Penjualan }\end{array}$ & $\begin{array}{l}\text { Pelaku UMKM } \\
\text { Kuliner di } \\
\text { Kecamatan Jebres }\end{array}$ \\
\hline 4 & $\begin{array}{l}\text { Para Pelaku UMKM Kuliner } \\
\text { belum memahami tentang } \\
\text { penjualan Online, khususnya } \\
\text { Go-Food. }\end{array}$ & $\begin{array}{l}\text { Pengenalan Aoplikasi } \\
\text { Penjualan Online dengan } \\
\text { Go-Food. }\end{array}$ & $\begin{array}{l}\text { Pelaku UMKM } \\
\text { Kuliner di } \\
\text { Kecamatan Jebres }\end{array}$ \\
\hline
\end{tabular}

\section{HASIL DAN PEMBAHASAN}

Pelatihan kepada pengusaha UMKM kuliner dilaksanakan pada Kamis dan Jumat, 27 dan 28 Agustus 2020, bertempat diWedangan Lawang Djoendjing, Mojosongo, Surakarta, dengan peserta sebanyak 15 orang pengusahan UMKM Kuliner dari Kecamatan Jebres. Instruktur berasal dari Tim Pengabdian pada Masyarakat FEB UNS dan Tim Go Jek Surakarta.

Hasil yang diperoleh selama Pelatihan dan Pendampingan Mitra Binaan seperti pada Tabel 3.

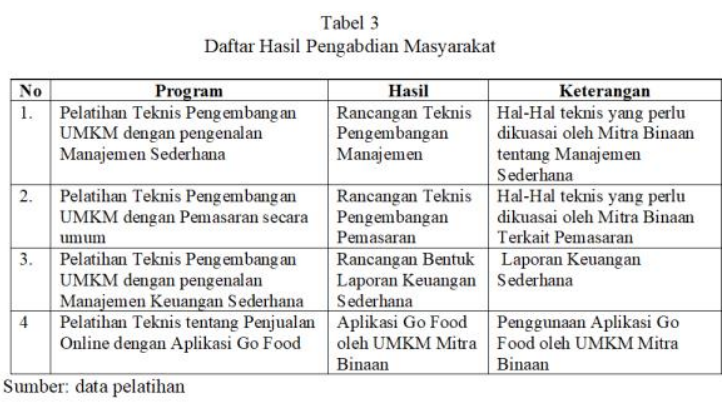

Pelatihan ini mendapat respon positif dari peserta yang terlihat dari atusiasme para peserta untuk mengikuti pelatihan dan berdiskusi hingga acara selesai. Materi disampaikan dengan bahasa yang sederhana sehingga mudah dipahami oleh peserta. Interaksi antara instruktur dengan peserta juga berjalan dengan lancar. Materi manajemen sederhana, manajemen pemasaran, manajemen keuangan mencakup pengertian, fungsi, dan penerapan sederhana di dunia nyata sehingga mudah diterapkan. Interaksi menandakan ketertarikan mereka terhadap materi yang dibahas.

\section{KESIMPULAN}

Kegiatan pengabdian masyarakat telah dilaksanakan dengan lancar sesuai yang direncanakan. Antausias para peserta pelatihan 
yang merupakan para UMKM kuliner yang berada di Kecamatan Jebres Surakarta sangat tinggi. Mereka mengikuti pelatihan dengan seksama untuk menerima materi manajemen, pembukuan, keuangan, pemasaran, dan penjualan online. Para peserta menerima penjelasan tentang penggunakan aplikasi penjualan online dengan Go-Food secara seksama. Mereka juga mulai menerapkan aplikasi tersebut sesuai dengan produk yang mereka miliki.

\section{UCAPAN TERIMAKASIH}

Pada kesempatan ini Tim mengucapkan terima kasih kepada LPPM UNS memberi dana untuk kegiatan ini dan khususnya kepada Tim dari GoJek Solo yang telah berpartisipasi memberi pelatihan dan pendampingan kepada para peserta pelatihan, sehingga para peserta bersemangat untuk meningkatkan penjualannya melalui penjualan online dengan Go-Food.

\section{REFERENSI}

Ali, Y. S. \& Ali, A. H. (2013). Entrepreneurship Development and Poverty Reduction: Empirical Survey from Somalia. American International Journal of Social Science, 2(3).

Ali, S., Rashid, H. \& Khan, M. A. (2014). The Role of Small and Medium Enterprises and Poverty in Pakistan: An empirical Analysis. Theoretical and Applied Economics, 11 (4): 67-80.

Budhi, M. K. (2013). Analisis Faktor-Faktor Yang Berpengaruh Terhadap Pengentasan Kemiskinan Di Bali. Jurnal Ekonomi Kuantitatif Terapan, 1(6)
Collier, P. (2007). Poverty Reduction in Africa. Centre for the Study of African Economies, Department of Economics, University of Oxford, Manor Road, Oxford, UK.

Green, C. J., Kirkpatrick, C.H. \& Murinde, V. (2006). Finance for small enterprise Growth and poverty reduction in Developing countriesy. Journal of International Development. 18: 10171030.

Harmadi, Rahardjo, M. \& Agung, W. (2012). Faktor-Faktor Percepatan Peningkatan Kesejahteraan Masyarakat di Kawasan Sangiran. LPPM UNS.

Lilik, S. (2008). Kontribusi Home Industry Dalam Meningkatkan Kesejahteraan Sosial Ekonomi Keluarga: Studi Kasus di Desa Wukirsari, Imogiri. AKMENIKA UPY, 2.

Ranjith, J.G. Sri Dan Banda, O. G Dayaratna. (2014). Determinants of Success of Small Business: A Survey-Based Study in Kuliyapitiya Divisional Secretariat of Sri Lanka. International Journal of Business and Social Research. (4):6.

Sudaryanto, T. \& Rusastra, I W. (2006). Kebijakan Strategis Usaha Pertanian Dalam Rangka Peningkatan Produksi Dan Pengentasan Kemiskinan. Jurnal Litbang Pertanian, 25(4).

Suwarno \& Mujiono. (2012). Analisis FaktorFaktor yang Mempengaruhi Tingkat Kemiskinan di Kabupaten Madiun. FEB. UPNV Jatim. 